\title{
Phenotypic and iPBS-retrotransposon marker diversity in okra (Abelmoschus esculentus (L.) Moench) germplasm
}

\author{
Faik Kantar ${ }^{\circledR}$, Sevde Nur Yemşen ${ }^{(\mathbb{C}}$, Cansu Bülbül*(D), Neslihan Yılmaz ${ }^{\circledR}$, Nedim \\ Mutlu
}

Department of Agricultural Biotechnology, Faculty of Agriculture, Akdeniz University, 07058, Antalya, Turkey.

\section{How to cite}

Kantar, F., Yemşen, S. N., Bülbül, C., Yılmaz, N., Mutlu, N. (2021). Phenotypic and iPBS-retrotransposon marker diversity in okra (Abelmoschus esculentus (L.) Moench) germplasm. Biotech Studies, 30(1), 7-15. https://doi.org/10.38042/biost.2021.30.01.02

\section{Article History}

Received 21 November 2020

Accepted 14 January 2021

First Online 27 January 2021

\section{Corresponding Author}

Tel.: +90 5546780704

E-mail:

cansusimsek91@hotmail.com

\author{
Keywords \\ Okra \\ Landraces \\ Agro-Morphologic \\ Molecular \\ Selection
}

\begin{abstract}
This study was undertaken to assess genetic and phenotypic diversity of Turkish okra (Abelmoschus esculentus (L.) Moench) germplasm of 26 landraces including three cultivars (Akköy-41, Kabaklı-11, and Marmara-1) with 34 phenotypic traits and 74 iPBSretrotransposon primers. Leaf-blade size, fruit length, fruit diameter, fruit number per plant, petiole length, plant height, stem diameter, number of stem nodes, and plant growth type (degree of branching) were the most important morphological traits contributing to the variation. Comparison of genotypes with 14 iPBS-retrotransposon primers yielded 141 bands, 34 of which (24.1\%) were polymorphic, with the primer 2271 producing the highest (6) bands per primer. Cluster analysis based on phenotypic and molecular markers produced two major groups. Phenotypic based unweighted pair group method with arithmetic mean (UPGMA) dendrogram had 12 sub-groups with the highest similarity (0.63) between GAN-19/GAN-21 and MGL-6/Akköy-41 genotypes. The markers, however, produced a dendrogram with eight subgroups, pairwise genetic similarities ranging from 0.43 to 1.00 , where MGL- 6 singled out with a similarity value of 0.57 . Howbeit, the Mantel test between both dendrograms based on the similarity matrix was insignificant.
\end{abstract}

\section{Introduction}

The okra, a member of the Malvaceae family, is taxonomically known as Abelmoschus esculentus (the binominal name is Abelmoschus esculentus (L.) Moench) and by the synonym Hibiscus esculentus L. Although the geographical origin of okra is controversial, it is thought to be originated from a tropical region of Asia or Africa (Tindall, 1983). West Africa was considered okra native land because of the presence of related wild species in the Nile Valley and Ethiopia (De Candolle, 1886; Yildiz et al., 2015a). Genetic studies have shown that okra's origin may consist of many species from Southeast Asia, India, West Africa, or Ethiopia. It was grown by the ancient Egyptians in the 12th century B.C., and its cultivation spread to the Middle East and North Africa (Lamont, 1999). Okra is cultivated in different tropical, subtropical, and warm temperature regions of the world Karakoltsidis \& Constantinides, 1975). Around 10 million tons of okra are produced worldwide, with most of its production in Asia and Africa. Today, India is the biggest okra producer with 6 million tons, followed by Nigeria, Sudan, and Mali, respectively. In Turkey, okra is annually grown on 5640 ha with a production of 29,111 tons (FAO, 2018). Because of the similarity of the okra germplasm in Turkey to the African germplasm, it is thought that Turkey's introduction to okra was due to the okras brought to Anatolia from the African continent (Duzyaman, 2009). Production in Turkey is widely with local types. Three commercial cultivars have been recently introduced in Turkey (TTSM, 2020).

In addition to having low essential fatty acid content, okra fruits contain important macromicroelements and vitamins (Al-Wandawi, 1983), and 
also another study have shown that okra seed is rich in unsaturated fatty acids (linoleic acid etc.) and high protein quality (Savello, 1980). Okra is not very selective in terms of soil, grown in tropical, subtropical and temperate regions of the world. Although it is a selfpollinated species, cross pollination can also be seen due to bees (Lamont, 1999). And this cross-pollination provides genetic variation that allows local okra genotypes to better adapt to environmental conditions. The chromosome number was reported to be $2 n=130$ (Joshi \& Hardas, 1956) but there are two kinds of okra genotypes diploid $(2 n=2 x=60-70)$ and tetraploids $(2 n$ $=4 x=120-130$ ) that were attributed to abnormalities in chromosome movement during the mitotic stage of cell division (Nwangburuka et al., 2011). It is an allopolyploid crop derived from the regular polyploid series with $n=12$ and has diploid chromosome number ranging between 72 and 144 (Datta \& Naug, 1968).

Interspecific hybridization is possible mechanism in the genus of Abelmoschus (Reddy, 2015), furthermore, the highest variation is seen in $A$. esculentus species, otherwise called the Saudanien type (Kalloo \& Bergh, 1993). It has been determined that there are very few or no distinguishing characteristics in the okra varieties in Turkey, Iran and India (Martin et al., 1981). Although okra in Turkey might differ from each other, it was determined that the original structure is preserved in okra germplasm resources (Duzyaman \& Vural, 2002). In the study with genotypes of different origins, it was shown that the morphology of Turkish okra is similar to those originating from India and Africa (Duzyaman \& Vural, 2000). Because of high phenotypic similarity among the germplasms of different origins, it becomes crucial to determine genetic variations using DNA markers. In this way, information on the genetic diversity required for the rational use of plant genetic resources can be obtained in the most reasonable way (Chakravarthi \& Naravaneni, 2006).

It is crucial for the agricultural policies of the countries to determine the genetic diversity by using molecular methods to preserve and develop varieties and lines with high yield, quality and adaptability. In this context, molecular markers have proven to be powerful tool in revealing genetic relationship intra and interspecies. There are different studies assessed the genetic diversity using sequence-related amplified polymorphism (SRAP) (Gulsen et al., 2007), random amplification of polymorphic DNA (RAPD) (Aladele et al., 2008; Prakash et al., 2011), simple sequence repeat (SSR) (Kumar et al., 2017), inter simple sequence repeat (ISSR) (Yuan et al., 2014), inter-primer binding site (iPBS) (Yildiz et al., 2015a; Yaldiz et al., 2018; Barut et al., 2020), microsatellite (Ravishankar et al., 2018) and amplified fragment length polymorphism (AFLP) (Akash et al., 2013) molecular markers in okra.

Retrotransposons are hereditary materials that assume a significant function in the plant genome regarding evolution, which can change the position and number of duplicates in the plant genome (Finnegan, 1989; Ali et al., 2019). "At the ends of the retrotransposons are long terminal repeats (LTRs) that qualify as a potential tRNA primer binding site (PBS)" (Finnegan, 1989). The iPBS markers are based on amplification of the PBS of the reverse transcriptase (tRNA complement) in two transposes opposite and close to each other (Kalendar et al., 2010). This study aimed to determine the genetic diversity among different local and commercial okra genotypes using both phenotypic and DNA-based iPBS-retrotransposon markers.

\section{Materials and Methods}

\section{Genotypes and cultivars}

Twenty-six okra genotypes of A. esculentus (L.) collected from different locations in Turkey were evaluated in this study (Figure 1; Table 1). Of these genotypes 20 okra accessions (BLK-1, MGL-2, MGL-3, MGL-4, MGL-5, MGL-6, MGL-7, MGL-8, MGL-9, MGL-10, AYD-11, AYD-12, AYD-13, MGL-14, UIS-15, UIS-16, USK17, AYD-18, GAN-19, GAN-21) were local genotypes collected by farmers from different locations in Turkey. Two (YLV-22 and YLV-23) were advanced breeding lines developed by Ataturk Central Horticultural Research Institute (ACHRS), Yalova. The list also included 3 commercially registered cultivars (Akköy-41, Kabaklı-11 and Marmara-1) obtained from ACHRS and one standard commercial type (STD-20).

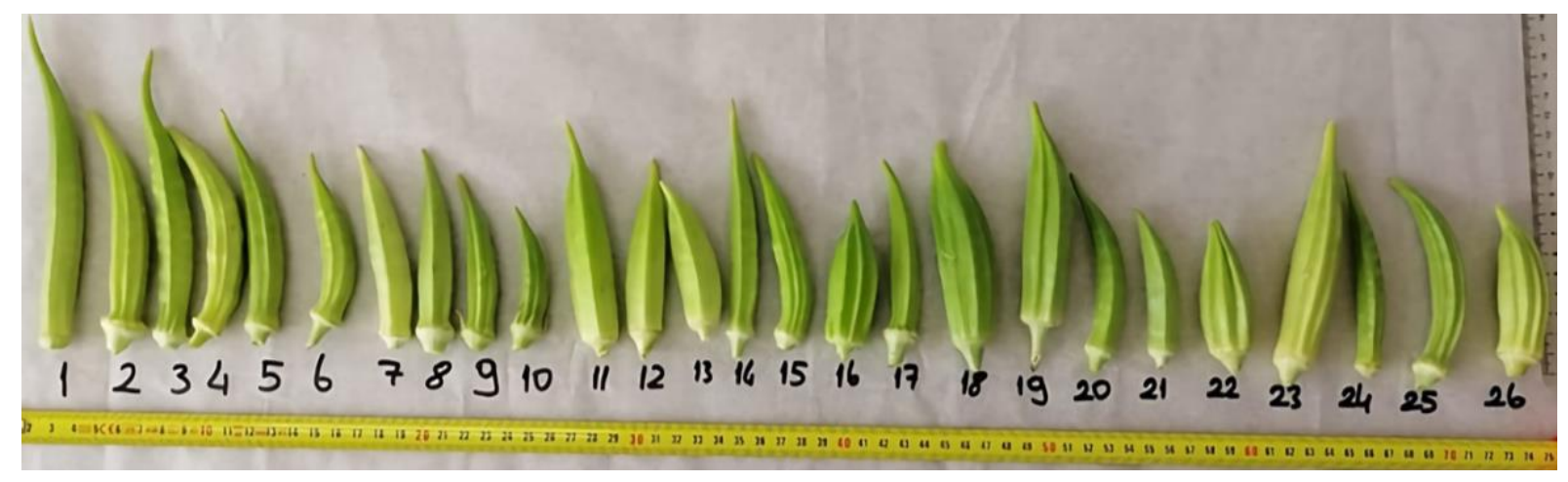

Figure 1. Okra genotypes and cultivars investigated in the experiment (numbers refer to row number in Table 1). 
Table 1. Okra germplasm, accession number, place of origin, source and their local names

\begin{tabular}{|c|c|c|c|c|}
\hline $\begin{array}{l}\text { Row } \\
\text { No }\end{array}$ & $\begin{array}{l}\text { Accession } \\
\text { No }\end{array}$ & $\begin{array}{l}\text { Geographical } \\
\text { Source }\end{array}$ & Source & Local Name \\
\hline 1 & BLK-1 & Gömeç/Balikesir & $\mathrm{PC}^{\mathrm{a}}$ & Local \\
\hline 2 & MGL-2 & Fethiye/Muğla & $\mathrm{PC}$ & Local \\
\hline 3 & MGL-3 & Fethiye/Muğla & PC & Local white \\
\hline 4 & MGL-4 & Fethiye/Muğla & $\mathrm{PC}$ & Local red \\
\hline 5 & MGL-5 & Fethiye/Muğla & PC & Local yellow \\
\hline 6 & MGL-6 & Seydikemer/Muğla & PC & Local mixed \\
\hline 7 & MGL-7 & Seydikemer/Muğla & PC & Local \\
\hline 8 & MGL-8 & Seydikemer/Muğla & PC & Local \\
\hline 9 & MGL-9 & Seydikemer/Muğla & PC & Local red \\
\hline 10 & MGL-10 & Seydikemer/Muğla & PC & Local \\
\hline 11 & AYD-11 & Aydın & PC & Local \\
\hline 12 & AYD-12 & Aydın & PC & Local \\
\hline 13 & AYD-13 & Sazlı/Aydın & PC & Local \\
\hline 14 & MGL-14 & Köyceğiz /Muğla & PC & Endeze \\
\hline 15 & UIS-15 & Ortaca/Muğla & PC & Local \\
\hline 16 & UIS-16 & Ortaca/Muğla & PC & Local \\
\hline 17 & USK-17 & Karahallı/Uşak & PC & Sultani \\
\hline 18 & AYD-18 & Köşk/ Aydın & PC & Tasbatan \\
\hline 19 & GAN-19 & Gaziantep & PC & Local \\
\hline 20 & STD-20 & Konya & SUNAGRI & Sultani \\
\hline 21 & GAN-21 & Gaziantep & $\mathrm{PC}$ & Local \\
\hline 22 & YLV-22 & Yalova & $\mathrm{ACHRS}^{\mathrm{c}}$ & $A B L^{b}$ \\
\hline 23 & YLV-23 & Yalova & ACHRS & $\mathrm{ABL}$ \\
\hline 24 & Akköy-41 & Yalova & ACHRS & $\mathrm{CC}^{\mathrm{d}}$ \\
\hline 25 & Kabaklı-11 & Yalova & ACHRS & $\mathrm{CC}$ \\
\hline 26 & Marmara-1 & Yalova & ACHRS & $\mathrm{CC}$ \\
\hline
\end{tabular}

aPC Personal Collection, ${ }^{b} \mathrm{ABL}$ Advanced breeding Line, ${ }^{\mathrm{C}} \mathrm{ACHRS}$ Ataturk Central Horticultural Research Institute, Yalova, Turkey, ${ }^{\mathrm{d} C o m m e r c i a l}$ Cultivar

\section{Production of plant material}

Seeds collected from each genotype were sown at Akdeniz University Faculty of Agriculture Experiment Farm. The soil was off clay loam texture with a slightly alkali $\mathrm{pH}$ of 7.62 , a high lime content of $17.7 \%$, good organic matter content of $2.1 \%$, total $\mathrm{N}$ content of $0.09 \%$, low $\mathrm{P}$ content $(0.0013 \%)$, high $\mathrm{K}$ content $(0.19 \%)$, high Ca content $(0.4 \%)$, optimum $\mathrm{Mg}$ content of $(0.09 \%)$ and $\mathrm{Mn}, \mathrm{Zn}, \mathrm{Cu}$ and Fe contents respectively 2.67, 0.47, 0.25 and $1.2 \mathrm{mg} / \mathrm{kg}$ respectively. Irrigation was applied as required with dripping system, standard fertilizer was applied, and hand weeding was performed during the plant growth period.

\section{Phenotypic/Agro-morphological traits measured}

The phenotypic data of okra ( $A$. esculentus (L.) Moench) were collected according to the criteria in the guidelines for conducting the distinctness, uniformity and stability described by International Union for the Protection of New Varieties of Plants (UPOV, 1999). A total of 34 traits were measured, including 7 agromorphological traits (seed yield per plot (SYP), seed weight per pod (SWPP), seed yield per plant (SYPP), thermal time requirements for flowering (TTRF), thermal time requirements for fruit formation (TTRFF), plant growth type (PGT) and suitability to mechanical harvest (STMH)). TTRF and commercial harvest time were calculated in degree days by average of the daily greatest and least temperatures recorded and compared to a base of temperature, $10^{\circ} \mathrm{C}$ (Dhankar \& Singh, 2013).

\section{DNA extraction}

Leaf samples from each genotype were collected from individual healthy green plants for molecular marker analysis. Genomic DNA was extracted from 40$50 \mathrm{mg}$ young fresh leaf tissue of individual genotypes, using 2\% CTAB method (Doyle \& Doyle, 1987) and all DNA concentration of each genotype was measured using $1 \%$ agarose gel.

PCR amplifications with iPBS-retrotransposon markers PCR amplifications were performed under reaction conditions containing $50 \mathrm{ng}$ DNA template, $0.2 \mathrm{mM}$ of each dNTPs (Thermo Fisher Scientific, USA) $0.2 \mu \mathrm{M}$ of each iPBS primers, 1X Taq Polimerase Buffer (from 10X stock ammonium buffer with $15 \mathrm{mM} \mathrm{MgCl}_{2}$ ), $1.25 \mathrm{U} / \mu \mathrm{l}$ Taq DNA polymerase (Ampliqon, Denmark) in the final volume using the following PCR conditions; 5 minute (min) denaturation at $95^{\circ} \mathrm{C}$ and 35 cycles of 30 second (s) denaturation at $95^{\circ} \mathrm{C}, 45 \mathrm{~s}$ annealing at $40-60^{\circ} \mathrm{C}$, and $1 \mathrm{~min}$ extension at $72^{\circ} \mathrm{C}$, followed by a final extension at $72^{\circ} \mathrm{C}$ for $10 \mathrm{~min}$. The PCR products separated on $1 \mathrm{X}$ TBE Buffer (90 mM Tris, pH 8.3, $90 \mathrm{mM}$ boric acid, $0.1 \mathrm{mM}$ EDTA) with $2 \%$ agarose gels (Sigma-Aldrich Chemie $\mathrm{GmbH}$, Germany) containing $0.5 \mu \mathrm{g} / \mathrm{ml}$ ethidium bromide (EtBr) and imaged under U.V. imaging system (DNR, Minilumi, Neve Yamin, Israel).

\section{Data analysis}

Polymorphic bands obtained by iPBSretrotransposon primers used in the study were scored as present (1) or absent (0) due to the dominant nature of marker system. A dendrogram was created in "Numerical Taxonomy Multivariate Analysis System (NTSYS-pc)" version 2.1 software package (Rohlf, 1992) using UPGMA method (Michener \& Sokal, 1957) to examine genetic relationships between genotypes. To create a dendrogram, DICE coefficient was based on the similarity matrix (Dice, 1945). Principal component analysis (PCA) was performed based on Jaccard similarity coefficient and two and three-dimensional graphs were created using the DCENTER and EIGEN procedures in NTSYS. Analysis was also made on phenotypic/agro-morphological data using SPSS statistical package (IBM, 2015) according to augmented statistical design. Similarity index was calculated and distance cluster dendrogram was created with S.M. coefficient and UPGMA method using NTSYS-pc ver. 2.1 software package. The eigen value of the phenotypic/agro-morphological data was calculated based on the similarity coefficient and of the variation explained. Comparison of marker and agromorphological data based on similarity matrices with Mantel test (Mantel, 1967) was performed.

\section{Results}

Variation in phenotypic/agro-morphological traits

Considerable variation was recorded for all the qualitative and quantitative plant traits investigated 
(Table S1). Higher variation was observed in quantitative traits compared with qualitative traits (Table S1). Variance was the highest in SYP $\left(26273.7 \mathrm{~g}^{2}\right)$ followed by TTRFF (2572.6-degree day ${ }^{2}$ ), and TTRF (2421.4-degree day $\left.^{2}\right)$, SYPP $\left(193.2 \mathrm{~g}^{2}\right)$, petiole length $(P L)\left(47.8 \mathrm{~cm}^{2}\right)$, diameter of young fruit (FD) $\left(29.2 \mathrm{~cm}^{2}\right)$ and length of mature fruit (LMF) $\left(25.3 \mathrm{~cm}^{2}\right)$. There were 3 -fold difference in plant height $(\mathrm{PH})$, ranging from $40.0 \mathrm{~cm}$ (GAN-19, MGL-7) to $120 \mathrm{~cm}$ (MGL-9) whereas stem diameter (SD) ranged from $4.58 \mathrm{~cm}$ (AYD-13) to $9.43 \mathrm{~cm}$ (MGL-9) (Table S1). FD ranged from $10.57 \mathrm{~mm}$ (BKL-1) to $26.69 \mathrm{~mm}$ (AYD-18) while diameter of mature fruit (DMF) ranged from $16.86 \mathrm{~mm}$ (Akköy-41) to $32.18 \mathrm{~mm}$ (UIS-16). Time of flowering (TF) was the earliest in MGL9 and BLK-1 (55 and 58 days) and the latest in USK-17 and GAN-21 (68 vs 72 days, respectively). The earliest harvest was obtained from MGL-9 (61 days), YLV-23 (62 days) and BLK-1 (63 days). The highest number of fruits was obtained from Marmara-1 (16) and MGL-8 (14). The fruit number per plant (FNP) ranged from 3 (AYD-11, AYD-12, MGL-6, MGL-7 and GAN-21) to 16 (Marmara-1) with a mean of 6.23 (Table S1).

PCA with 34 traits produced 9 components with eigen values explaining $85.8 \%$ of total variation where the first 2 explaining $23.4 \%$ and $17.1 \%$ of variance, respectively (data not presented). The first three components explained $52.9 \%$ of cumulative variance. Leaf blade size (LBS) (0.793), SYP (0.756), flower size (FS) (0.754), (FNP) (0.695), PH (0.657), LMF $(0,653)$, SD $(0,639)$ and fruit thickness of carpel (TFC) $(0.603)$ had the highest contributions in the first component whereas SWPP (0.658), FD (0.608), stem number of nodes (NSN) (0.603) and seed yield per plant (SYPP) $(0.602)$ had the highest values in the second component as opposed to PGT (plant growth type) (0.721) having the highest value in the third component (data not presented).

The biplot for PCA of the first two components discriminated 4 groups of traits that distinctly comprised plant for quantitative (PH, SD etc.), color (fruit color (FC), stem color (SC) etc.), shape (fruit shape of apex (FSI), fruit constriction of basal part (CFBP) etc.) and phenological traits (TF, TFH etc.) (Figure 2). Shape and color traits were closely related while phenological and quantitative traits were more clearly separated (Figure 2). Shape and color traits are grouped on the negative part of $X$ and $Y$ axis while quantitative traits were positioned on the positive scale of $X$ and $Y$ axis. Time related traits were positioned on $\mathrm{Y}$ axis (Figure 2). NSN, STMH, DMF, TFC, FNP, PL, FS, LBS, plant growth type (PDB), petiole diameter (PD) and number of fruit locules (NFL) appeared to be the most important agromorphological traits positively relating to yield (SWPP, SYPP and SYP).

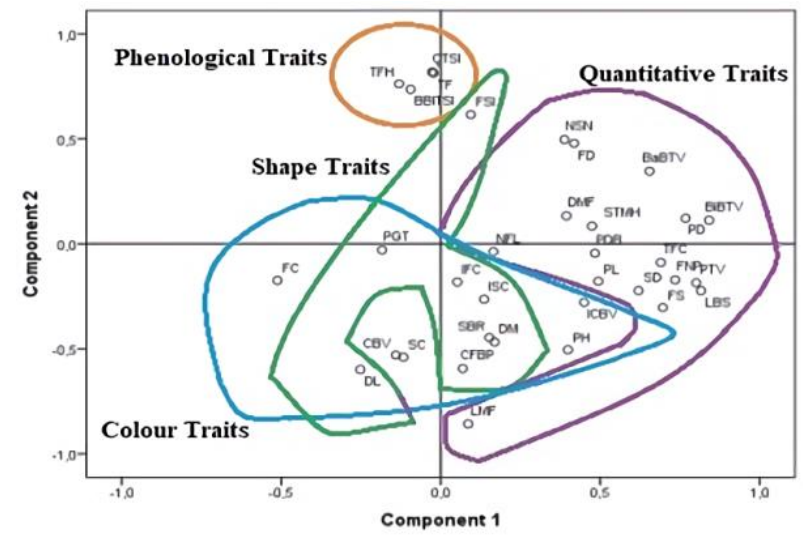

Figure 2. Biplot and PCA on phenotypic/agro-morphological traits investigated of okra genotypes and cultivar.

\section{Cluster analysis based on qualitative and quantitative phenotypic traits}

In line with cluster analysis of 27 phenotypic data described by UPOV, the dendrogram was created according to the UPGMA method and as a result, the existence of two major groups and different sub-groups under these major groups were determined. The highest similarity (0.63) was seen between GAN-19/GAN-21 genotypes collected from Gaziantep region and MGL6/Akköy-41 genotypes. MGL-2 and MGL-9 genotypes formed a separate group in the dendrogram (Figure 3 ). The first two eigen values explained $21.05 \%$ of the total variation. In addition, 2D/3D plots of agromorphological data were obtained by PCA analysis (Figure 4; Figure 5).

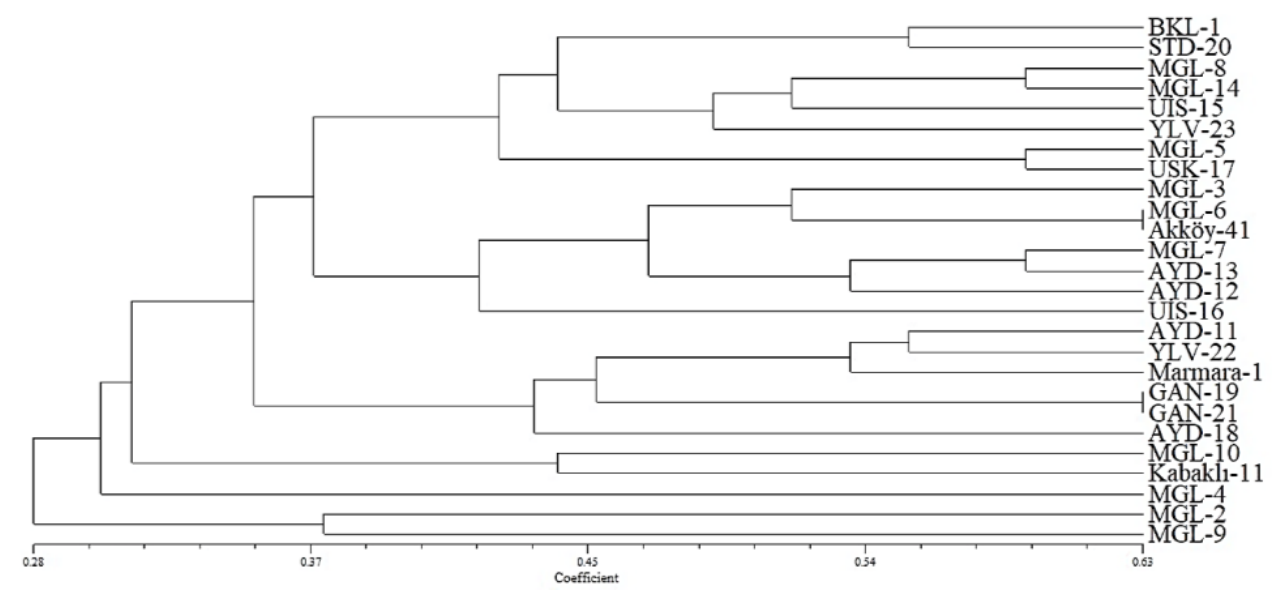

Figure 3. UPGMA similarity dendogram of local okra ecotypes based on qualitative and quantitative phenotypic traits. 


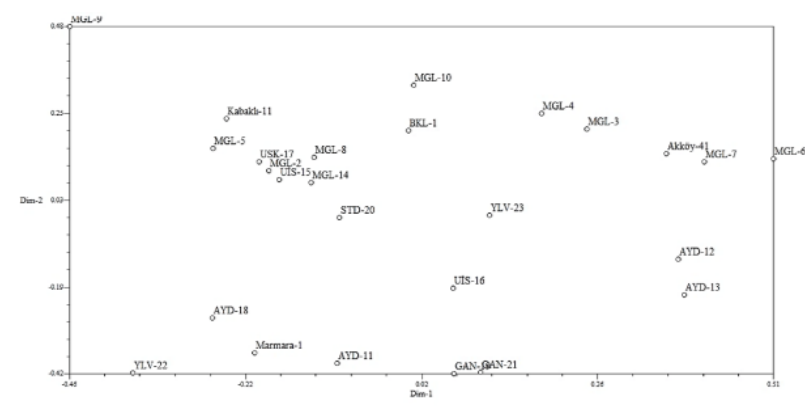

Figure 4. Two-dimensional plot of PCA of 26 okra genotypes based on phenotypic traits. Dim-1 and Dim-2 explain $10.76 \%$ and $10.29 \%$ of variation, respectively.

\section{Comparison of genotypes with iPBS-retrotransposon primers}

Initially, 74 iPBS-retrotransposon primers were used to screen the bulk DNAs of okra genotypes for amplification. Then 14 iPBS-retrotransposon primers were determined yielding polymorphic and highly reproducible bands. In this study, a total of 26 okra genotypes collected from different locations in Turkey were analysed with 14 different polymorphic IPBSretrotransposon primers to determine the genetic relationship between genotypes.

At the same time, characterization study was carried out according to various criteria, and the data obtained were compared with iPBS marker and the correlation between the two dendograms was determined by the Mantel test. The 14 primers (2271, 2379, 2095, 2393, 2238, 2388, 2243, 2249, 2087, 2270, $2390,2272,2382,2384)$ yielded 141 bands, 34 of which $(24.1 \%)$ were polymorphic. One to six polymorphic band was obtained per primer. The primer 2271 yielded the highest (6) while the primers 2390, 2272, 2382, 2384 produced the lowest number of polymorphic bands (1) per primer. Polymorphic band sizes ranged from 230 to $2200 \mathrm{bp}$ in size while the average number of bands and polymorphic markers per primer was 10.07 and 2.42, respectively (Table 2 ).

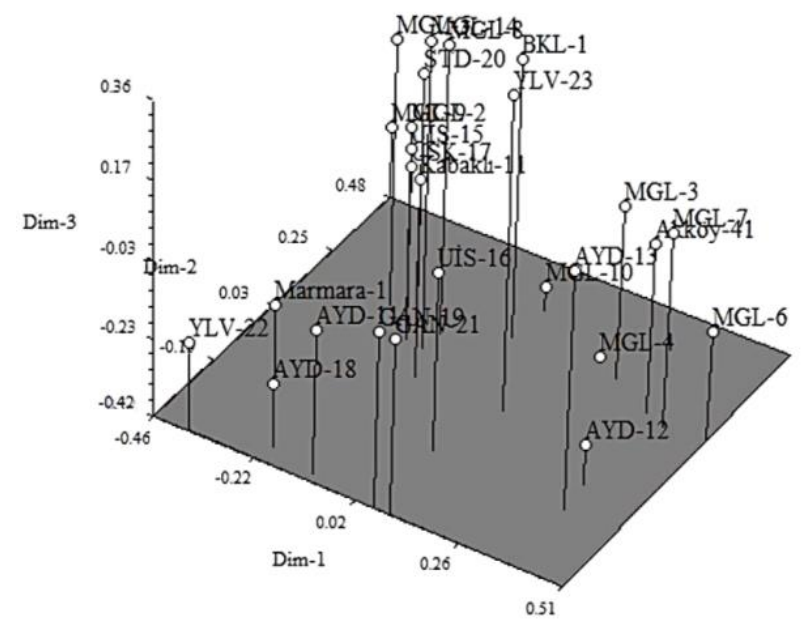

Figure 5. Three-dimensional plot of PCA of 26 okra genotypes based on phenotypic traits. Dim-1, Dim-2, and Dim-3 explain $10.76 \%$ and $10.29 \%$ and $8.25 \%$ of variation, respectively.

\section{Cluster Analysis Based on iPBS-retrotransposon Markers}

As a result of the dendrogram created, the existence of 2 different major groups was determined. Pairwise genetic similarities ranged from 0.43 to 1.00 and maximum similarity value of 1.00 were observed between 4 genotypes (MGL-3, MGL-9, AYD-11, AYD-13). iPBS markers failed to separate the four genotypes from each other. MGL-7 genotypes created a different group, separating from the rest in dendrogram with 0.57 genetic similarity. The remaining 25 genotypes were distinguished from one another with similarity values ranging from 0.57 to 1.00 . Among the 25 genotypes, the MGL-6 genotype differed with a similarity value of 0.57 (Figure 6). The first two eigen values (2.63 and 1.86, respectively) obtained with PCA explained $36.1 \%$ of the total variation. The $2 \mathrm{D}$ and $3 \mathrm{D}$ graphs showed a similar result with dendrogram and most of the genotypes clustered together, especially MGL-3, MGL-9, AYD-11, AYD-13 genotypes with similarity values of 1.00 were clustered in a close area with STD-20 cultivars in this

Table 2. Genetic analysis of 14 polymorphic iPBS-retrotransposons markers with 26 Okra genotypes

\begin{tabular}{|c|c|c|c|c|c|}
\hline Primers & Sequence & $\operatorname{Tm}\left({ }^{\circ} \mathrm{C}\right)$ & $\begin{array}{c}\text { Total Band } \\
\text { Numbers }\end{array}$ & $\begin{array}{c}\text { Polymorphic } \\
\text { Band Numbers }\end{array}$ & $\begin{array}{c}\text { Product Sizes for } \\
\text { Polymorphic Bands (bp) }\end{array}$ \\
\hline 2271 & GGCTCGGATGCCA & 54.3 & 11 & 6 & $500-2000$ \\
\hline 2379 & TCCAGAGATCCA & 41.5 & 9 & 4 & $400-1500$ \\
\hline 2095 & GCTCGGATACCA & 44.8 & 11 & 3 & $280-600$ \\
\hline 2393 & TACGGTACGCCA & 47.1 & 10 & 3 & $400-650$ \\
\hline 2238 & ACCTAGCTCATGATGCCA & 55.5 & 10 & 3 & $260-1250$ \\
\hline 2388 & TTGGAAGACCCA & 43.4 & 10 & 3 & $300-1250$ \\
\hline 2243 & AGTCAGGCTCTGTTACCA & 54.9 & 11 & 2 & $1900-2200$ \\
\hline 2249 & AACCGACCTCTGATACCA & 54.7 & 11 & 2 & $500-2000$ \\
\hline 2087 & GCAATGGAACCA & 43.5 & 10 & 2 & $230-250$ \\
\hline 2270 & ACCTGGCGTGCCA & 56.9 & 10 & 2 & $600-800$ \\
\hline 2390 & GCAACAACCCCA & 47.6 & 11 & 1 & 600 \\
\hline 2272 & GGCTCAGATGCCA & 50.5 & 7 & 1 & 260 \\
\hline 2382 & TGTTGGCTTCCA & 44.9 & 11 & 1 & 1000 \\
\hline 2384 & GTAATGGGTCCA & 40.9 & 9 & 1 & 400 \\
\hline Total & & & 141 & 34 & \\
\hline Average & & & 10.07 & 2.42 & \\
\hline
\end{tabular}




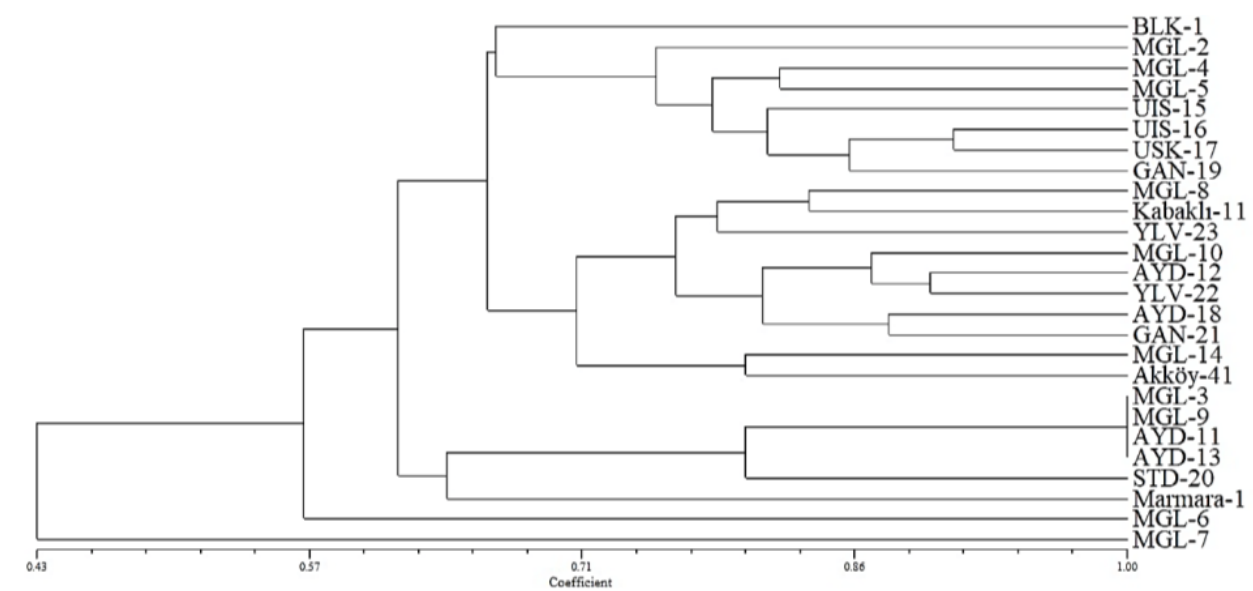

Figure 6. Dendrogram of 26 okra genotypes constructed by UPGMA based on IPBS-retrotransposon markers.

graph and formed a separate group. MGL-7 was located on the graph in a region separate from the group clusters (Figure 7; Figure 8).

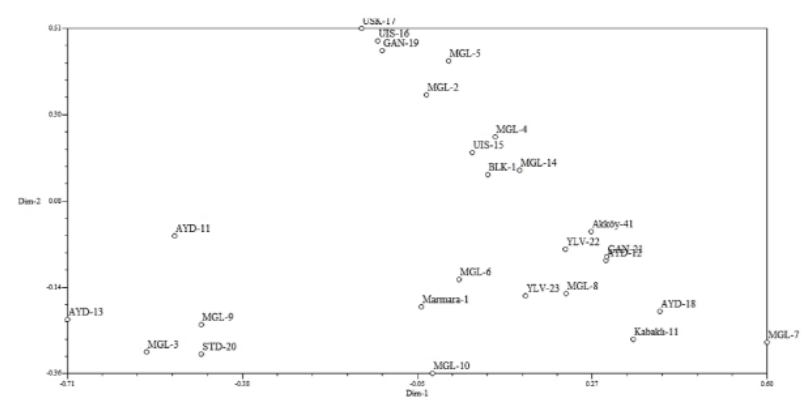

Figure 7. Two-dimensional plot of PCA of 26 okra genotypes based on iPBS-retrotransposon markers. Dim-1 and Dim-2 explain $21.12 \%$ and $14.98 \%$ of variation, respectively.

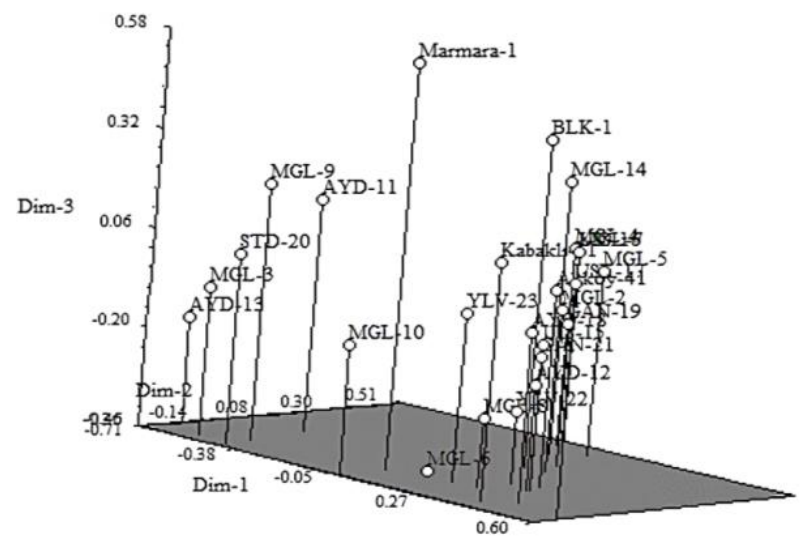

Figure 8. Three-dimensional plot of the principal component analysis (PCA) of 26 okra genotypes based on iPBSretrotransposon markers. Dim-1, Dim-2, and Dim-3 explain $21.12 \% 14.98 \%$ and $9.86 \%$ of variation, respectively.

\section{Discussion}

The okra germplasm including 3 commercial cultivars showed considerable variation in the qualitative and quantitative plant growth descriptive traits investigated. LBS, FL, FD, PL, FNP, PH, SD, NSN and PDB were the most important quantitative characteristics contributing to variation within the germplasm. Yildiz et al. (2015b) working with 30 okra genotype and 35 morphological traits reported that fruit, leaf, stem color, leaf shape, flower size, fruit-surface angularity, petal color were important characteristics to distinguish the okra accessions.

Duzyaman (2005) working with 11 Turkish genotypes and 25 morphological, horticultural and physiological characteristics found that number of locules, mature pod length and internode length, pod yield/plant, pod number/plant, pedicel length and number of branches were main traits contributing the variability. Days to first flowering, nodes per plant, length of internode, fruit weight and fruits per plant were the most important traits contributing to heterosis in okra breeding (Bhatt et al., 2016). The higher number of accessions and descriptors were suggested in order to characterise better the representative regional morphotypes (Martin et al., 1981). Earliness and fruit yield as well fruit size and fruit color are important traits for consumers and producers. The germplasm we investigated had considerable variability for the traits that may serve as genetic material for a breeding program. The germplasm included landraces with thinner fruits (STD-20), short but thicker fruits, late maturing (GAN-21), determinate growth type (AYD-13), shortest plant height (MGL-7), thinner fruit diameter (MGL-6), shortest plants and fruits (GAN-19), highest seed yield (MGL-2), late, highest seed yield (USK-17), low fruit diameter (UIS-15), wider fruit diameter, easy harvest brittle fruit stems (UiS-16), dark green fruits (AYD-18), early, taller plants, long fruits (MGL-9), wide fruit diameter (YLV-22), taller plants and fruits (BKL-1), high seed yield (MGL-14) and earliness, higher fruit number (MGL-8). Although it was not a planned descriptive trait, brittleness of fruit stems discerned during harvest of UIS-16 could be an important quality for developing easily harvestable cultivars while dark green fruits of AYD-18 and very early flowering MGL-9 may contribute to genetic variation. Small okra pods of 2-4 days $(<4 \mathrm{~cm})$ are preferred largely in Turkey (Duzyaman \& Vural, 2003b) whereas larger pods (>7-8 
$\mathrm{cm})$ are marketed in North America and India (Duzyaman \& Vural, 2003a). Slower fruit fibre development in some cultivars (Kyriakopoulou et al., 2014) may be suitable for marketing long pods. Further work is required for the investigation of late fibre development properties of genotypes in Turkish germplasm in order to extend marketability of okra. This quality may compensate disadvantages of early harvest failure and exploit fruit yield potential of okra genotypes. Cultivars with earliness, easily harvestable traits, higher yield and superior market value may boost commercial potential of okra. Assessing genetic diversity of germplasm is crucial before establishing successful breeding programs.

Although the difference between okras in Turkey is usually determined by morphological properties, we have shown that iPBS markers can contribute to differentiate okra genotypes. Hence, both molecular and qualitative-quantitative agro-morphological traits were used to genotype and phenotype the 26 okra genotypes collected from different locations in Turkey. iPBS-retrotransposon marker systems, previously used to define the relationship between genotypes in different plant species (Barut et al., 2020; Yaldiz et al., 2018). Polymorphism was obtained for 26 okra genotypes using 14 of the 74 iPBS-retrotransposon primers used in the study. The polymorphism rate was $24.11 \%$. At the same time, significant phenotypic variations were identified in terms of different characters handled within the local okra genotypes from different locations. Dendrograms created using molecular and agro-morphological data showed that two major groups exist among the genotypes. As a result of marker-data analysis, MGL-3, MGL-9, AYD-11, AYD-13 and also STD-20 genotypes are similar in terms of both dendogram and 2D/3D graph. The first two eigen values explained $36.1 \%$ of the total variation. Based on agromorphological clustering, genotypes collected from similar location were determined to be located close to each other in the dendrogram. The highest similarity (0.63) was obtained with the GAN-19 and GAN-21 genotypes collected from the same location. Akköy-41 and Marmara-1 varieties were in a separate group than Kabaklı-11. However, in the dendrogram and 2D/3D graphs created by iPBS-retrotransposon molecular marker system, Kabaklı-11 and Akköy-41, developed from Sultani, were in the main group with the Sultani type standard variety (STD-20), while Marmara-1, a plump variety, was in the other group. The first two eigen values obtained as a result of analysis of agromorphological data explained $21.05 \%$ of the total variation. Correlation between marker-based and agromorphological-based dendrogram created according to similarity matrix was determined with Mantel test, was, however, insignificant $(r=-0.11)$.

Marker-assisted molecular studies on okra are rare in the world. Previously, there were only two molecular marker studies with okra genotypes found in Turkey where SRAP, iPBS and SSR molecular markers were used
(Gulsen et al., 2007; Yildiz et al., 2015a). At the end of a study using 66 okra genotypes and 13 polymorphic IPBSretrotransposon primers, 88 bands and $40.2 \%$ total polymorphism rates were obtained as a result (Yildiz et al., 2015a). Higher total polymorphism rates of Yildiz et al. (2015a) probably originated from higher number of genotypes tested.

Gulsen et al. (2007) using 31 Turkish and 2 randomly selected U.S. genotypes and applying 39 SRAP primer combinations obtained approximately $50 \%$ of the 97 bands obtained which were polymorphic for 23 genotypes. It was determined that 17 of these 23 genotypes were separated from each other with an average of 0.93 similarities. However, although the UPGMA dendrogram based on 33 phenotypic markers distinguished all genotypes, the geographic relationship between okra genotypes was not detected.

In another study with 44 okra genotypes collected from different locations in India, a total of 104 bands were obtained with 14 RAPD primers randomly amplifying the genome, and $74.03 \%$ polymorphism was obtained. These 14 primers were found to make a clear distinction between genotypes (Prakash et al., 2011). The reason for the higher rate of polymorphism obtained in their study was the fact that main centre of origin of okra is Indian subcontinent with considerable variation. Another reason for the higher polymorphism rates obtained is thought to be the use of the RAPD molecular marker system, which probably provides random amplification to produce a higher number of bands. Work on the assessment of okra germplasm is not sufficient and hence further studies are required with higher number of landraces, accessions, lines and cultivars representing major okra growing areas and dominant types in Turkey. Many of the previous work cited varied in the traits investigated. Further studies should apply wider number of marker systems and commercial cultivars as well as morphological descriptors universally used by breeders of okra plant. It was reported that genetic base of Turkish okra germplasm is narrow requiring inclusion of external diversity to national collections to increase variability (Yildiz et al., 2015b). Because of this narrow genetic base, polymorphism detected by limited number of molecular marker systems was low and hence further work is required with the inclusion of the external germplasm having the qualitative and quantitative traits scarce in Turkish national gene pool and testing new marker systems and phenotypic markers.

\section{Conclusion}

LBS, LMF, FD/DMF, PL, FNP, PH, SD, NSN, and PDB were the most important characteristics contributing to the variation in the okra germplasm. The 14 iPBS primers yielded 141 markers, 34 of which (24.1\%) were polymorphic. Cluster analysis based on phenotypic and iPBS-retrotransposon data produced two major groups with 12 and 8 subgroups respectively without any 
significant correlation between the two in Mantel test. Selection of parents in okra breeding program by phenotypic descriptors in conjunction with iPBSretrotransposon marker system may aid better selection for conservation and breeding studies.

\section{Acknowledgements}

This work "Examination of morphological variation in local okra (Abelmoschus esculentus L.) genotypes collected from Turkey" contains morphological/phenotypic data presented to Akdeniz University for M.Sc. dissertation thesis by Neslihan Yılmaz.

\section{Author Contribution}

FK: Conceptualization, Data Curation, Formal Analysis, Methodology, Project Administration, Resources, Supervision, Validation, Visualization, Writing - review and editing; SNY: Formal Analysis; CB: Formal Analysis, Investigation, Visualization, Writing Original Draft Preparation; NY: Formal Analysis, Data Curation; and NM: Conceptualization, Methodology, Project Administration, Supervision, Validation, Writing - review and editing.

\section{Additional Information}

Supplementary data accompanies this paper at http://biotechstudies.org/uploads/BIO-132 Supp1.pdf

\section{References}

Akash, M.W., Shiyab S.M., \& Saleh M.I. (2013). Yield and AFLP analyses of inter-landrace variability in okra (Abelmoschus esculentus L.). Life Science Journal, 10(2), 2771-2779.

http://www.dx.doi.org/10.7537/marslsj100213.385

Aladele, S.E., Ariyo O.J., \& De Lapena, R. (2008). Genetic relationships among West African okra (Abelmoschus caillei) and Asian genotypes (Abelmoschus esculentus) using RAPD. African Journal of Biotechnology, 7(10), 1426-1431. https://doi.org/10.5897/AJB08.006

Ali, F., Yılmaz, A., Nadeem, M. A., Habyarimana, E., Subaşı, I., Nawaz, M. A., Chaudhary, H. J., Shahid, M. Q., Ercişli, S., Zia, M., Chung, G., \& Baloch, F. S. (2019). Mobile genomic element diversity in world collection of safflower (Carthamus tinctorius L.) panel using IPBSretrotransposon markers. PloS One, 14(2), e0211985. https://doi.org/10.1371/journal.pone.0211985

Al-Wandawi, H. (1983). Chemical composition of seeds of two okra cultivars. Journal of Agricultural and Food Chemistry, 31(6), 1355-1358. https://doi.org/10.1021/jf00120a051

Barut, M., Nadeem, M. A., Karaköy, T., \& Baloch, F. S. (2020). DNA fingerprinting and genetic diversity analysis of world quinoa germplasm using iPBS-retrotransposon marker system. Turkish Journal of Agriculture and Forestry, 44(5), 479-491. https://doi.org/10.3906/tar2001-10
Bhatt, J.P., Patel, N.A., Acharya, R.R., \& Kathiria, K.B. (2016). Heterosis for yield and its related traits in Okra (Abelmoschus esculentus L. Moench). Electronic Journal of Plant Breeding, 7(1), 189-196. https://doi.org/10.5958/0975-928X.2016.00026.0

Chakravarthi, B.K., \& Naravaneni, R. (2006). SSR Marker based DNA Fingerprinting and Diversity study in rice (Oriza sativa. L). African Journal of Biotechnology, 5(9), 684 688. https://doi.org/10.5897/AJB05.172

Datta, P.C., \& Naug, A. (1968). A few strains of Abelmoschus esculentus (L.) Moench their karyological in relation to phylogeny and organ development. Beiträge zur Biologie der Pflanzen, 45, 113-126.

De Candolle, A. (1886). Origin of cultivated plants (2d American ed.). D. Appleton, New York. https://doi.org/10.5962/bhl.title.55127

Dhankar, S.K., \& Singh, S. (2013). Thermal requirement for flowering and fruit yield attainment in advance lines of okra. Journal of Agrometeorol, 15(1), 39-42.

Dice, L.R. (1945). Measures of the amount of ecologic association between species. Ecology, 26, 297-302. https://doi.org/10.2307/1932409

Doyle, J.J., \& Doyle, J.L. (1987). A rapid DNA isolation procedure for small quantities of fresh leaf tissue. Phytochemical Bulletin, 19, 11-15.

Duzyaman, E., \& Vural, H. (2000). Different approaches of the improvement process in some local okra varieties. In II Balkan Symposium on Vegetables and Potatoes, 579, 139-144.

https://doi.org/10.17660/ActaHortic.2002.579.20.

Duzyaman, E., \& Vural, H. (2002). Farklı ekocoğrafik kökenli bamya genotiplerinin morfolojik varyabilitesi üzerinde bir araştırma. Ege Üniversitesi Ziraat Fakültesi Dergisi, 39(2), 17-24.

Duzyaman, E., \& Vural, H. (2003a). Evaluation of pod characteristics and nutritive value of okra genetic resources. Acta Horticulturae, 598, 103-110. https://doi.org/10.17660/ActaHortic.2003.598.15

Duzyaman, E., \& Vural, H. (2003b). Managing the variability in okra breeding pro-grams by considering the preferences of the domestic market. Acta Horticulturae, 598, 129135. https://doi.org/ 10.17660/ActaHortic.2003.598.18

Duzyaman, E. (2005). Phenotypic diversity within a collection of distinct okra (Abelmoschus esculentus) cultivars derived from Turkish land races. Genetic Resources and Crop Evolution, 52, 1019-1030. https://doi.org/10.1007/s10722-004-6118-9

Duzyaman, E. (2009). Okra in Turkey domestic landraces. In: Okra Handbook Global Production, Processing, and Crop Improvement (Dhankhar B.S. \& Singh R., eds.). HNB Publishing, New York, 475, 323-346.

FAO, (2018). FAOSTAT. Retrieved October 11, 2020, from http://www.fao.org/faostat/en/ - data/QC/.

Finnegan, D.J. (1989). Eukaryotic transposable elements and genome evolution. Trends in Genetics, 5, 103-107. https://doi.org/10.1016/0168-9525(89)90039-5

Gulsen, O., Karagul, S., \& Abak K. (2007). Diversity and relationships among Turkish okra germplasm by SRAP and phenotypic marker polymorphism. Biologia, 62(1), 41-45. https://doi.org/10.2478/s11756-007-0010-y

IBM, (2015). IBM SPSS Statistics for Windows, Version 23.0. Armonk, New York.

Joshi, A. B., \& Hardas, M. W. (1956). Alloploid Nature of Okra, Abelmoschus esculentus (L.) Monech. Nature, 178(4543), 
https://doi.org/10.1038/1781190a0

Kalendar, R., Antonius, K., Smýkal, P., \& Schulman, A.H. (2010). IPBS: a universal method for DNA fingerprinting and retrotransposon isolation. Theoretical and Applied Genetics, 121(8), 1419-1430. https://doi.org/10.1007/s00122-010-1398-2

Kalloo, G., \& Bergh, B.O. (1993) Genetic improvement of vegetable plants (1st ed.). Pergamon Press, Oxford.

Karakoltsidis, P.A., \& Constantinides, S.M. (1975). Okra seeds. New protein source. Journal of Agricultural and Food Chemistry, 23(6),

1204-1207. https://doi.org/10.1021/jf60202a041

Kumar, S., Parekh, M.J., Fougat, R.S., Patel, S.K., Patel, C.B., Kumar, M., \& Patel, B.R. (2017). Assessment of genetic diversity among okra genotypes using SSR markers. Journal of Plant Biochemistry and Biotechnology, 26(2), 172-178. https://doi.org/10.1007/s13562-016-0378-2

Kyriakopoulou, O.G., Arens, P., Pelgrom, K.T.B., Bebeli, P., \& Passam, H.C. (2014) Genetic and morphological diversity of okra (Abelmoschus esculentus [L.] Moench.) genotypes and their possible relationships, with particular reference to Greek landraces. Scientia Horticulturae, 171, 58-70. https://doi.org/10.1016/j.scienta.2014.03.029

Lamont, W.J. (1999). Okra-A versatile vegetable crop. HortTechnology, 9, 179-184.

Mantel, N. (1967). The detection of disease clustering and a generalized regression approach. Cancer Research. 27(2), 209-220.

Martin, F.W., Rhodes, A.M., Ortiz, M., \& Díaz, F. (1981). Variation in okra. Euphytica, 30(3), 697-705. https://doi.org/10.1007/BF00038798

Michener, C.D., \& Sokal, R.R. (1957). A quantitative approach to a problem of classification. Evolution, 11, 490-499. https://doi.org/10.1111/j.1558-5646.1957.tb02884.x

Nwangburuka, C. C., Kehinde, O. B., Adegbite, O. A., \& Denton, O. A. (2011). Mitotic chromosomes in Abelmoschus esculentus (L.) Moench esculentus (L.) Moench. Annals of Biological Research, 2(4), 85-90.

Prakash, K., Pitchaimuthu, M., \& Ravishankar, K.V. (2011). Assessment of genetic relatedness among okra genotypes (Abelmoschus esculentus (L.) Moench) using RAPD markers. Electronic Journal of Plant Breeding, 2(1), 80-86.

Ravishankar, K.V., Muthaiah, G., Mottaiyan, P., \& Gundale, S.K. (2018). Identification of novel microsatellite markers in okra (Abelmoschus esculentus (L.) Moench) through next-generation sequencing and their utilization in analysis of genetic relatedness studies and cross-species transferability. Journal of Genetics, 97(1), 39-47. https://doi.org/10.1007/s12041-018-0893-0

Reddy, M. T. (2015). Crossability Behaviour and Fertility Restoration Through Colchiploidy in Interspecific Hybrids of Abelmoschus esculentus $\times$ Abelmoschus manihot subsp. tetraphyllus. International Journal of Plant Science and Ecology, 1(4), 172-181.

Rohlf, J.F. (1992). NTSYS-pc, Numerical Taxonomy and Multivariate Analysis System, version 2.1, Exeter Publishing, LTD, New York.

Savello, P.A., Martin, F.W., \& Hill, J.M. (1980). Nutritional composition of okra seed meal. Journal of Agricultural and Food Chemistry, 28(6), 1163-1166. https://doi.org/10.1021/jf60232a021

Tindall, H.D. (1983). Vegetables in the Tropics (1st ed.). Macmillan Press Ltd., London. https://doi.org/10.1007/978-1-349-17223-8

TTSM, (2020). Republic of Turkey Ministry of Agriculture and Forestry Variety Registration and Seed Certification Center (TTSM) Ankara, Turkey. Retrieved November 10, 2020, from https://www.tarimorman.gov.tr/BUGEM/TTSM/.

UPOV, (1999). Guidelines for the conduct of test for distinctness, uniformity and stability, of okra (Abelmoschus esculentus (L.) Moench). International Union for the Protection of New Varieties of Plants, TG/167/3, Geneva.

Yaldiz, G., Camlica, M., Nadeem, M. A., Nawaz, M. A., \& Baloch, F. S. (2018). Genetic diversity assessment in Nicotiana tabacum L. with iPBS-retrotransposons. Turkish Journal of Agriculture and Forestry, 42(3), 154-164. http://doi.org/ 10.3906/tar-1708-32

Yildiz, M., Kocak, M., \& Baloch, F.S. (2015a). Genetic bottlenecks in Turkish okra germplasm and utility of iPBS retrotransposon markers for genetic diversity assessment. Genetics and Molecular Research, 14(3), 10588-10602. http://dx.doi.org/10.4238/2015

Yildiz, M., Ekbic, E., Duzyaman, E., Serce, S., \& Abak, K. (2015b). Genetic and phenotypic variation of Turkish Okra (Abelmoschus esculentus L. Moench) accessions and their possible relationship with American, Indian and African germplasms. Journal of Plant Biochemistry and Biotechnology, 25(3), 234-244. http://dx.doi.org /10.1007/s13562-015-0330-x

Yuan, C.Y., Zhang, C., Wang, P., Hu, S., Chang, H.P., Xiao, W.J., Lu, X.T., Jiang, S.B., Ye, J.Z., \& Guo, X.H. (2014). Genetic diversity analysis of okra (Abelmoschus esculentus L.) by inter-simple sequence repeat (ISSR) markers. Genetics and Molecular Research, 13(2), 3165-3175. http://dx.doi.org/10.4238/2014 